\title{
A Quality Approach to Masters Education Using an Australian Case Study -- A Reflection
}

\author{
Lauren P Richardson ${ }^{1, *}$, Carol G McGowan ${ }^{2}$, Lee E J Styger ${ }^{1}$ \\ ${ }^{1}$ Sydney Business School, University of Wollongong, Sydney, Australia \\ ${ }^{2}$ Faculty of Business, University of Wollongong, Wollongong, Australia
}

Copyright $\bigcirc 2018$ by authors, all rights reserved. Authors agree that this article remains permanently open access under the terms of the Creative Commons Attribution License 4.0 International License

\begin{abstract}
By the start of 2015 all University courses in Australia were required to be compliant with the new the Australian Qualifications Framework (AQF). Quality in higher education seeks to achieve three goals - quality of design, quality of conformance and quality of performance. This paper brings together a number of higher education principles such as double loop learning, team teaching and heutagogy in order to satisfy these quality requirements. A pilot program was established to satisfy the changes to the Australian regulatory framework for tertiary education. The paper streamlines integrated ways to bring these aspects together that have not previously been identified in higher education publications. The specific focus is for an MBA course delivered in an Australian regional university. The result is a reflection of the application of the newly devised quality principled based heutagogical double loop learning cycle. The model can assist educational administrators and course developers to facilitate students in becoming independent lifelong self-motivated capable learners while at the same time ensuring the quality assurance principles are met.
\end{abstract}

Keywords Quality Higher Education, Master Business Administration, Masters Education, Heutagogical Learning Cycle, Heutagogy, Team Teaching

\section{Introduction}

Masters of Business Administration (MBA) courses are the flagship courses offered by universities. It is a highly competitive field when trying to attract students. Therefore, being able to provide a visible point of difference is essential. This paper provides a reflective look, using a case study approach, on how an Australian University attempted to provide this point of difference by using a quality heutagogical approach while simultaneously complying with changes to tertiary education expectations within the overall education framework operating in
Australia. The approach adopted consolidated a number of essential elements of tertiary education such as heutagogy incorporating double-loop learning and team teaching. This was against a backdrop of employing Deming's Plan-Do-Check-Act (PDCA) approach to Quality which when adapted to higher education becomes Plan-Do-Assess-Improve (PDAI). This paper will outline how these factors were brought together to achieve the desired outcomes of the diverse stakeholder groups with an interest in the process including: students, government agencies, educational standards and university practices.

\section{Background}

The Australian Government in 2013 released the 2nd edition of the Australian Qualifications Framework (AQF). This was a major overhaul of the previously existing framework and would necessitate all tertiary institutions to reconfigure how their courses were developed and delivered. The framework established guidelines for regulated education qualifications [1]. It was therefore imperative to bring into line the Masters of Business Administration and program requirements with a comprehensive review of all Level 9 subject to ensure students developed "specialized knowledge and skills for research and/or professional practice and/or future learning" [2].

\subsection{The Australian Qualifications Framework Requirements for a Master's Degree Subject}

The factors that steered the creation of the new subject were to:

- Meet regulatory AQF requirements

- Create a subject that meets the requirements for a level 9 Masters course

- Assist in the adoption of a heutagogical method to learning

- Cultivate students into skilled, capable and flexible 


\section{lifelong learners}

- Implement a team teaching tactic to ensure optimum subject matter coverage

There are five key dimensions that needed to be addressed to ensure compliance to $\mathrm{AQF}$ requirements these include: purpose, knowledge, skills, application and volume of learning. Graduates of a 900 level course must exhibit judgement, expertise, adaptability, autonomy and responsibility as a learner [2]. A foundation subject for the MBA program was developed to deliver students the "tools and concepts necessary to understand and perform professionally within the academic and business world" [3] The subject's predominant purpose was to develop transferable business capabilities, skills and methods pivotal to forthcoming career success underpinned by a desire for lifelong learning.

\section{Literature Search}

\subsection{Overview}

A revised integrative literature review method based on Torraco [4] and Whittemore and Knafle [5] guided the analysis. This approach allows for an amalgamation of research and literature types. It allows for an incorporation of a variety of sources where little research has been done. To determine the current status regarding AQF compliance in an MBA degree course a literature search was undertaken. Our survey of the literature on Masters Business Education was non-exhaustive, given many dealt with Vocational or Masters Level but not specifically an MBA. We undertook searches in Education Research Complete, Web of Science and Scopus on-line databases. The search was refined to peer-reviewed journal articles. We focused our search using the keywords AQF or "Australian Qualifications Framework" and MBA or "Masters of Business Administration". The articles needed to address the following criteria:

- The key topic of the article was MBA courses and AQF compliance

- To discuss and afford information regarding: the process, models, methods, implementation of MBA courses in Australia

A combination of keywords in the three databases identified 112 articles; in which 1 matched the criteria. In this article Hall et al., [6] have highlighted the fact that there is considerable pressure in Australia for management education to change and how MBA's are presently tackling the internal and external forces impacting business education. Hence any course developed will need to accommodate and be aware of a variety of global expectations not just those that specifically exist within Australia. It was discovered that 27 articles discussed AQF compliant courses. The articles identified relating to
AQF compliant courses in the university sector covered a wide diversity of disciplines and subject areas including: accounting [7]; business coaching [8]; economics [9]; event management [10]; health degrees [11]; law [12]; sciences [13]; broad tertiary focus [14]; employment outcomes or precise skills [15]; Vocational Education and Training (VET) courses [16]; and undergraduate courses [17]. Others simply conversed about their programs or skills but were not connected to the AQF and were omitted.

Given there was a paucity of literature in the specific area under review of MBA courses and $\mathrm{AQF}$ compliance other factors related to quality tertiary education were reviewed and analyzed for their relevance. The specific areas identified as most relevant for our purposes were:

- Quality in Education

- Heutagogy

- Team Teaching

\subsection{Quality in Higher Education}

Approaches to adult learning is a topic regularly discussed within the university context. Options available regularly and routinely change [18]. Trying to keep up with the latest ideas of what constitutes good quality practice can be time consuming and confusing as the validity for various points of view are well argued and supported by evidence [19-21]. The expectations of universities are changing with changes in society, hence knowing where to start and trying to keep up can be challenging.

Quality is a term often applied to business but not as frequently to education [22], while this article does not specifically apply to Australia the principles espoused to achieve quality higher education are universal identifying three prongs of quality that need to be considered and addressed to ensure a quality product is produced. These are:

- Quality of Design - this considers the characteristics or features the product or service (in this case masters subject) would need to contain

- Quality of Conformance - this factor looks at does the product or service conforms to the specifications set out for it (i.e.: compliance to $\mathrm{AQF}$ requirements)

- Quality of Performance - does the product or service deliver as expected by the marketplace in this case students, universities, governments etc.

These aspects highlight there is a mindset that needs to be applied to quality practice that underpins every action taken to ensure final results satisfy expectations and mechanisms are in place to constantly monitor that.

Continuous improvement is a cornerstone of quality and this aspect is a critical component of a quality approach which is implemented through the use of Deming's Plan (P) - Do (D) - Check (C) - Act (A) cycle. Aggarwal and Lynn [23] suggest that there is an adaptation of this cycle 
particularly relevant for higher education which they call the Plan (P) - Do (D) - Assess (A) - Improve (I) cycle and this is the one that is relevant for our purposes. Figure 1 highlights how this approach is utilized and is the approach adopted when developing this subject to help ensure compliance to $\mathrm{AQF}$ requirements.

Figure 1 explains how PDAI is applied within a Higher Education context. These factors and considerations provided the backdrop for how all the work was undertaken related to the development of a MBA AQF compliant course. How these factors were specifically utilized in the design and delivery of this course will be explained in Section 4 Design in Table 1 where it explains how these were applied during design, delivery and post-delivery of the course.

Having established the underlying approach to be used it was then necessary to consider generic higher education approaches to determine their relevance and suitability achieving the requirements of the identified stakeholder groups. This then lead to reviewing the literature on these concepts. The following sections will discuss heutagogy incorporating double loop learning and team teaching and why they are relevant to achieving the stated objectives for this course.

\section{THE PDAI MODEL FOR HIGHER EDUCATION}

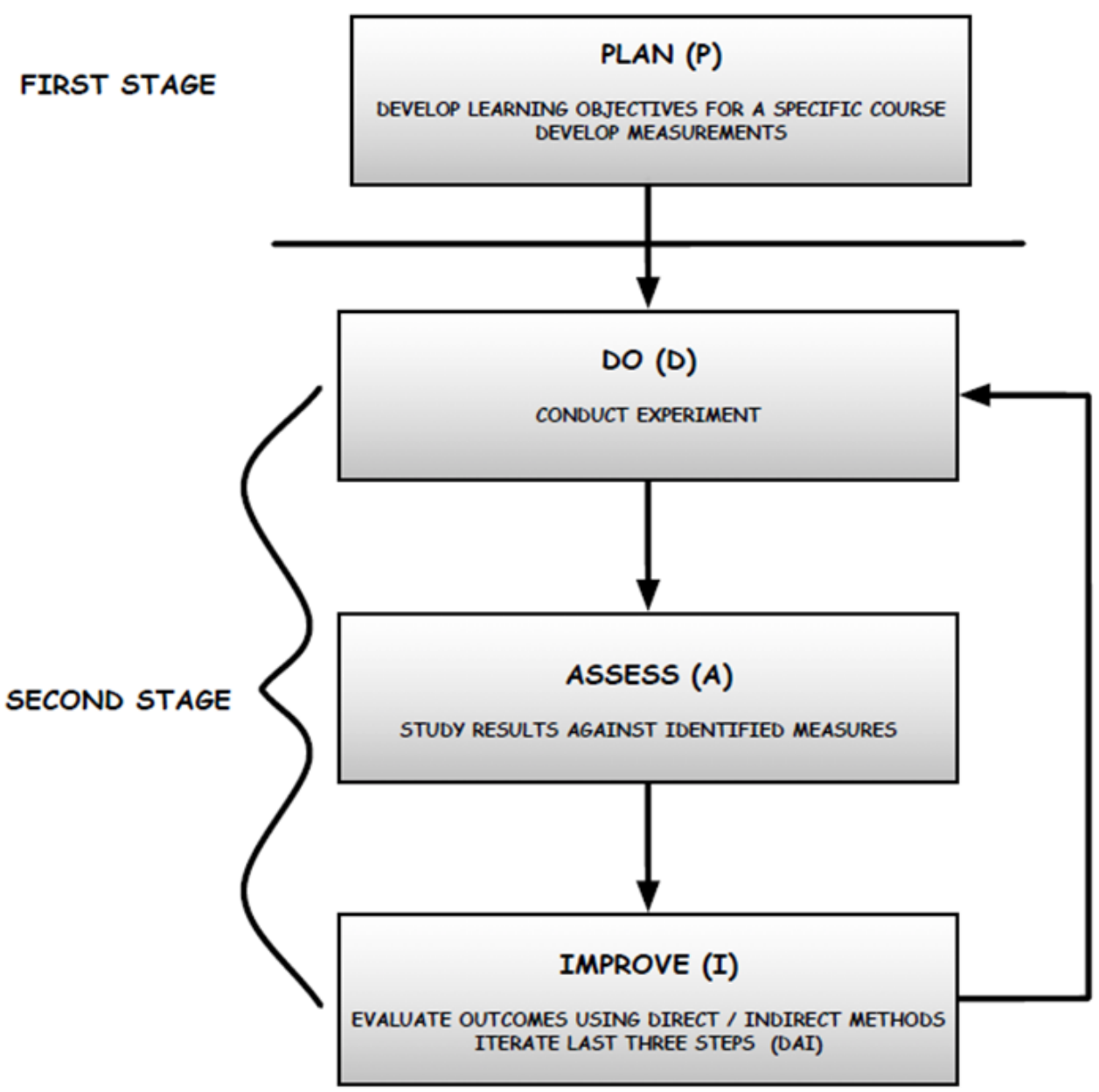

Figure 1. The PDAI Model for Higher Education adapted from [21] 
Table 1. Application of PDAI to an AQF Compliant MBA course

\begin{tabular}{|c|c|c|c|c|}
\hline $\begin{array}{c}\text { Stage } 3 \text { - Post } \\
\text { Delivery Review }\end{array}$ & & & $\begin{array}{l}\text { - Conduct comprehensive } \\
\text { post-delivery review with } \\
\text { Course Co-Ordinator } \\
\text { - Review student evaluations for } \\
\text { feedback }\end{array}$ & $\begin{array}{l}\text { Adjust or develop new } \\
\text { materials for the next } \\
\text { time the course is } \\
\text { delivered }\end{array}$ \\
\hline $\begin{array}{l}\text { Stage } 2 \text { - } \\
\text { Delivery }\end{array}$ & & $\begin{array}{l}\text { - Present course } \\
\text { materials } \\
\text { - Conduct in-class } \\
\text { discussions } \\
\text { - Conduct in-class } \\
\text { exercises } \\
\text { - Allow time for } \\
\text { students to } \\
\text { complete their } \\
\text { worksheets } \\
\text { - Give students time } \\
\text { to access suitable } \\
\text { resources }\end{array}$ & $\begin{array}{l}\text { - Review in-class worksheets } \\
\text { - Double mark assessments to } \\
\text { ensure consistency of } \\
\text { assessment } \\
\text { - Conduct post class debriefs } \\
\text { between educators } \\
\text { - Debrief students experience of } \\
\text { the activities as part of their } \\
\text { opportunity to guide their } \\
\text { learning experience }\end{array}$ & $\begin{array}{l}\text { - Adjust in-class activities } \\
\text { - Update course materials } \\
\text { - Discuss options with } \\
\text { Course Co-Ordinator }\end{array}$ \\
\hline Stage 1 - Design & $\begin{array}{l}\text { - Determine working } \\
\text { arrangements } \\
\text { between educators } \\
\text { - Review and assess } \\
\text { regulatory } \\
\text { requirements } \\
\text { - Determine } \\
\text { university } \\
\text { requirements } \\
\text { - Determine subject } \\
\text { requirements and } \\
\text { learning outcomes }\end{array}$ & $\begin{array}{l}\text { - Develop operating } \\
\text { agreement } \\
\text { between educators } \\
\text { - Develop subject } \\
\text { learning outcomes } \\
\text { - Develop Subject } \\
\text { outline for } \\
\text { approval } \\
\text { - Develop } \\
\text { assessments and } \\
\text { grading rubrics } \\
\text { - Develop course } \\
\text { materials } \\
\text { - Develop in-class } \\
\text { worksheets by } \\
\text { topic }\end{array}$ & $\begin{array}{l}\text { - Submit course materials for } \\
\text { approval i.e.: } \\
\text { - Subject outline } \\
\text { - Course materials } \\
\text { - In-class worksheets } \\
\text { - Assessments } \\
\text { - to course co-ordinator for } \\
\text { approval }\end{array}$ & $\begin{array}{l}\text { Make adjustments to } \\
\text { course resources as } \\
\text { identified by Course } \\
\text { Co-ordinator }\end{array}$ \\
\hline \begin{tabular}{|c|}
$\begin{array}{c}\text { Stage of } \\
\text { Development }\end{array}$ \\
Phase of Quality \\
Cycle \\
\end{tabular} & Plan(P) & Do(D) & $\operatorname{Assess}(\mathrm{A})$ & Improve(I) \\
\hline
\end{tabular}

Table 2. Comparative Analysis of Pedagogy, Andragogy and Heutagogy adapted from [56]

\begin{tabular}{|c|c|c|c|}
\hline Comparative Elements & $\begin{array}{c}\text { Pedagogy: } \\
\text { Teacher Lead Learning }\end{array}$ & $\begin{array}{c}\text { Andragogy: } \\
\text { Self-directed learning }\end{array}$ & $\begin{array}{c}\text { Heutagogy: } \\
\text { Self-determined learning }\end{array}$ \\
\hline Dependence & $\begin{array}{l}\text { - The learner is dependent on } \\
\text { the teacher }\end{array}$ & $\begin{array}{l}\text { The learner is } \\
\text { interdependent - they are } \\
\text { autonomous in their learning } \\
\text { proc ess }\end{array}$ & $\begin{array}{l}\text { The learner is a problem finder - } \\
\text { they know the destination and are } \\
\text { interdependent of those who can } \\
\text { help them get there }\end{array}$ \\
\hline Reasons for Learning & $\begin{array}{l}\text { - } \text { Trust placed in teacher } \\
\text { - Learning is linear and } \\
\text { sequential } \\
\text { - Learner has little } \\
\text { responsibility for learning }\end{array}$ & $\begin{array}{l}\text { Learner looks for guidance } \\
\text { and mentorship } \\
\text { - Learner seeks to take on } \\
\text { more responsibility for } \\
\text { learning }\end{array}$ & $\begin{array}{l}\text { - Learning is not linear or sequential } \\
\text { - Learner is fully responsible for their } \\
\text { learning } \\
\text { - Learners welcome challenges and } \\
\text { 'good luck' in their learning process }\end{array}$ \\
\hline Focus of Learning & $\begin{array}{l}\text { - Learning is subject focussed } \\
\text { - Learning needs to comply } \\
\text { with specific curricula }\end{array}$ & $\begin{array}{l}\text { - Learning is goal-driven } \\
\text { - Learning encourages } \\
\text { cross-disciplinary thinking } \\
\text { and is autonomous }\end{array}$ & $\begin{array}{l}\text { - Learning is based on enquiry } \\
\text { - Learning takes a long-term view } \\
\text { - Learners are not daunted by } \\
\text { complexity and uncertainty }\end{array}$ \\
\hline Motivation for Learning & $\begin{array}{l}\text { Motivation for learning is } \\
\text { extrinsic i.e.: external to the } \\
\text { learner e.g.: parents, teachers } \\
\text { etc. }\end{array}$ & $\begin{array}{l}\text { Motivation for learning is } \\
\text { intrinsic i.e.: learners like } \\
\text { the enhancement to their } \\
\text { self-esteem that comes from } \\
\text { learning }\end{array}$ & $\begin{array}{l}\text { - Motivation comes from } \\
\text { experiencing 'flow' and that they } \\
\text { know how to learn } \\
\text { - Learners seek unfamiliar situations } \\
\text { to acquire adaptive competence }\end{array}$ \\
\hline Role of Teacher & $\begin{array}{l}\text { Educator is the one who } \\
\text { designs the learning and } \\
\text { identifies appropriate } \\
\text { learning materials and } \\
\text { resources }\end{array}$ & $\begin{array}{l}\text { Facilitator sets the tasks } \\
\text { encouraging the student to } \\
\text { use various routes to identify } \\
\text { solutions }\end{array}$ & $\begin{array}{l}\text { Coach attempts to bring together } \\
\text { opportunity, context, relevance and } \\
\text { complexity to encourage } \\
\text { collaboration and curiosity }\end{array}$ \\
\hline
\end{tabular}




\subsection{Heutagogy a Necessary Learning Philosophy}

The current workplace requires a proficiency in its workforce that can deal with a volatile, multifaceted and complex environment [24]. As a result of this professionals find themselves in a continuous state of change, hence in order to survive one of the requirements is that they participate in lifelong learning [25]. The focus of an MBA is for students to obtain the skills to undertake their professions and be able to be analytical, problem solvers, research savvy, critical thinkers that are reflective lifelong learners that will equip them to cope in a dynamic, multifaceted and complex environment. With this in mind it was important to find a philosophy to higher education that would support these requirements. This has led to an investigation to identify the most appropriate approach for MBA courses with the parameters identified by the Australian Qualifications Framework.

One of the common discussions related to higher education is the need for good pedagogy which then shifted to suggesting that good andragogy was the best option and in more recent times heutagogy has surfaced as the more optimal approach to adult education. Table 2 will provide a comparative analysis of the three philosophical approaches to adult/higher education. What this table shows is that there are elements of pedagogy, andragogy and heutagogy that are relevant for educational endeavors within an MBA course. It is important that trust is placed in the teacher an important precept of pedagogy, it is necessary that the learner is independent and autonomous and that they have access to guidance and mentorship to aid them in their learning process key precepts of andragogy and yet this is not enough. What is needed in this instance is for the learner to be a problem finder, to be able to learn in a non-linear way, to welcome challenges, to be curious and capable of dealing with complexity and uncertainty key components of a heutagogical approach. Each of these aspects is in alignment with the requirements of the $\mathrm{AQF}$ where they are expecting that students will develop specialist skills and knowledge to use in personal and professional areas and to encourage a desire for lifelong learning by facilitating a sound basis to scaffold future learning as a part of their Masters education.

Some other factors that make heutagogy the most appropriate philosophical approach is that it is self-determined learning, it is forward looking education philosophy where knowing how to learn is a fundamental skill necessary to handle the speed of change within our current organizations [26]. The learner is placed at the centre of the learning experience. There are two approaches to heutagogy the first is mentor assisted learning and the other solution based [27]. Mentor assisted learning was considered to be the most appropriate in this instance. Mentor assisted learning is when mentees are guided and supported by mentors by adopting the tactic of motivation and encouragement to assist in adjusting to university and life, to develop their own learning landscape, construct their own internalized patterns of reasoning and to negate anxieties [28]. The aim of TBS900 was to convert Masters Students to heutagogical lifelong learners by developing the fundamental skill of knowing how to learn [29].

Lifelong learning is seen as a continuous and self-motivated act to build on one's own knowledge [28]. The features of this type of learning include [25]:

- Advancement occurs through a learner centred demand-driven education.

- It is underpinned by strong self-motivation [30,31];

- Occurs through opportunity and diverse experiences and not from textbooks;

- $\quad$ Arises in a multitude of forms for development and personal accomplishment;

- Can occur in a variety of circumstances and contexts;

- Does not only occur through teaching [32];

- Can appear to arise in the 'nick of time';

- Sensory experience can boost personal knowledge;

- Can be facilitated through team and group interactions

There is some contention about the suitability of this approach in a university environment. It is considered more relevant to vocational education because real world problem solving is more easily facilitated as part of the learning process [18]. However, MBA courses are less impacted by discipline specific requirements found in specialized professional courses such as medicine, accounting, law and engineering. Therefore, the ability to employ heutagogical principles is less constrained by professional bodies credentialing guidelines. It is expected that by the time a student undertakes an MBA course they have completed any credentialing requirements of their profession through other avenues other than the MBA where the objective is to learn good general leadership, management and business practice which can be applied across a wide range of contexts and is not discipline specific.

A less obvious and yet vital aspect of the heutagogical approach is that it employs a double-loop learning approach incorporating critical self-reflection into the educational process [26]. Critical self-reflection is central to being a lifelong learner [25]. Reflection enables information to be taken in, understood and adjusted into future activities [33]. The ability to reflect allows students to assimilate fresh information, to consider its relevance to previous knowledge thus enabling the ability to adapt current behavior, learning styles, opinions and expectations centred on their learnings [34]. It was realized that by giving students a chance for critical self-reflection through assessments students would be given an opportunity to convert theoretical frameworks and academic insights into to practically applied business skills that could be used in future studies or employment.

Taking all these factors into account it was considered 
that the heutagogical approach was the most appropriate in this instance. Once realizing that heutagogy was the underlying philosophy for development of this course then consideration was given to how the course would actually be delivered to students. Given that a diverse range of subject areas was to be discussed and explained to students it became apparent that having one lecturer for the whole course would be insufficient. This then led on to the consideration of an embedded team teaching approach. This will be discussed in the following section.

\subsection{Embedded Team Teaching Approach}

Team teaching is the cooperation between instructors who possess divergent specialties of expertise, who are mutually responsible for providing students with a strong educational foundation [35]. Embedded refers to the method in which competences, both academic and business skills, are linked to the content and assessments of the subject [36]. It is accepted that it is the duty of the lecturer to mentor and embed both academic literacies and professional skills into the subject [29, 37]. Nevertheless, not all lecturers are proficient literacy and business skills educators. Thus, a team teaching method was implemented. The formed partnership between a subject expert and academic literacy professional enabled the delivery and ability to mentor students in developing both business and academic skills successfully [38]. Chandra and Sottile[35] have highlighted several pros of team teaching which include: labor is distributed, exposes student to different perspectives and knowledge professionals, it creates an interaction that is not obtainable with a solo lecturer. There are also some cons to this approach which include: increased time required to prepare course materials, potential for personality conflicts, potentially less time to get to know students in depth, diverse styles and approaches to working with students. While there was recognition of the cons associated with this approach it was felt that having more than one lecturer would provide the greatest benefit to the students. Some of the key factors that influenced the decision to go ahead with a team teaching approach from the student perspective were: that it would expose students to differing opinions something they will experience in their workplace contexts, to encourage creativity and critical thinking allowing for the discovery of alternative paths and solutions and ultimately it would enable an environment where the students had the ability to influence the learning that took place by having a choice of guides to help facilitate that process. From the educator perspective factors that influenced the decision to use a team teaching approach included: it would enable an opportunity for a dynamic educational context, demonstrate the value of team teaching in this type of environment and practically demonstrate the value of productive working partnerships. Each of these factors aligns with the concepts of adopting a heutagogical approach to adult education.

\section{Design}

\subsection{Case Study}

Given the uniqueness of the circumstances for the creation of this course and the lack of existing literature specifically related to the application of AQF to an MBA course it was deemed most relevant to use a case study approach for the purposes of analysis. Case studies provide a real-life context to ask the how and why questions of the world [39]. This method is widely known and has been applied and validated in numerous areas including education, sociology and psychology [40-42]. It is viewed as a stand-alone contribution as the study provides insights, understanding and investigation into workplace practices in this instance and educational institution i.e.: university [43]. A single case study was chosen as this case provides the opportunity to act as a point of difference from previous theoretical views [44] in that it has enabled the exploration of the development of an AQF compliant subject in an MBA course which is predicated on the use of proven quality principles in a higher education context. It was an opportunity to explore the application of the PDAI quality management and heutagogical principles to provide a double looped learning model. The aim is to create a quality approach to lifelong learning and offers a way forward to develop student's abilities to be continuous learners. While this scenario appears unique to Australia what makes it relevant on a more universal level is that most universities need to be able to find a way to satisfy a variety of stakeholder requirements that can be as a result of regulatory requirements, university expectations or learning requirements of a specific course. This is a fairly common experience within the university context irrespective of where the university is situated.

\subsection{Design Principles: How the New MBA Subject Was Developed}

The overall approach adopted was to utilize a quality approach to Masters Education using heutagogy supported by employing a team teaching approach. The following discussion of the case study under review will outline the specific steps undertaken to achieve the stated requirements of all relevant stakeholders. Table 1 represents is how the steps of PDAI were applied to the design, delivery and review of the requisite course. It shows as represented in Figure 1 that Planning sets the foundation (the key phase for the design stage) for what is to come and that the Do(D)-Assess(A)-Improve(I) steps are iterative and continue to occur throughout until the activity is completed. 
The foundational (initial) subject TBS900 Managing for Success had the purpose of introducing students to the required skills and competencies they will need to complete their entire MBA and also to enhance their existing professional capabilities and competencies. The purpose of the subject was to apply Blooms taxonomy [45] to facilitate the student's transition from using low level thinking skills to high level analysis, synthesis and evaluation. TBS 900 was significant in that students cultivated their academic and business skills including their personal and professional development competencies focusing on the specific business capabilities and competencies to be developed which include: business writing, business presenting, interpretation of business data and the ability to undertake business research. The more personal and relationship skills needed includes: survival and resilience skills, time management skills, creative skills and teamwork skills.

\subsection{TBS900 Delivery Mode and Schedule}

The requirements of this course necessitated that it be delivered across 2 geographically separated campuses at the University in Wollongong Main Campus and the Sydney Campus 80 kilometres away. These classes were on alternative weekends over an 11-week trimester. Classes were provided in intensive mode from 9 am to 5 $\mathrm{pm}$ Saturday and Sunday. The subject required students to complete 5 distinct and diverse assessment tasks as well as participate in class activities, discussion and reflection.

\subsection{TBS900 Content Development}

The main challenges were that this was a completely new course and required us to traverse a previously unknown terrain. The subject's content was constructed in three stages: initiation, formation and finalization. Initiation: the University and $\mathrm{AQF}$ requirements were evaluated and that lead to the selection of the content and tools needed. We looked at the considerations outlined by Bauwens and Hourcade[46] those being philosophical considerations of the heutagogy learning method, theoretical considerations of how team teaching could be implemented. Procedural considerations the processes and practices of the subject delivery, instructional considerations for skills and knowledge transfer while evaluation considerations of the forms of assessment tools used to identify student development. The Formation developed the subject content and outlines in-class activities, assessment, marking criteria and rubrics. Finalization was attained when the Head of the School authorized the subject outline. The subject content was constructed throughout the five allocated face to face days. Every day was divided into 4 sessions i.e.: morning, before lunch, after lunch and afternoon. In order to cover the three core areas of personal development, study skills and employability skills 1 hour 45 minutes was allocated to each session. To assist in the students' personal development of these core areas numerous methods were undertaken. In-class activities and worksheets were used to further student collaboration and participation (individually and in teams). Class discussions and worksheets aided the critical analysis, reflection and evaluation of the topics. Assessments determined comprehension, judgement and application of resources and knowledge gained. A combination of Deming [47], Kolb [48] and Inamdar and Roldan [49] cycles were used to provide the ideological lens of theory, practical, applied and reflective to expedite the application of skills and knowledge by the students.

\subsection{Connection to Heutagogical Practice}

As stated previously heutagogy is a method that acknowledges that intuition is an integral part of the lifelong learning process when it is combined with reflective and double loop learning practices [29]. At the centre of lifelong learning is the ability to learn from and in action [25]. Critical reflection forms the base of this learning. We merged several frameworks of learning, like the well-known Deming[47] cycle: Plan, Do, Check, Act, in this case represented as Plan-Do-Assess-Improve (PDAI) as well as Kolb's experimental learning cycle, Dennick's[50] twelve tips for incorporating educational theory into teaching practices, Blaschke's [51] Heutagogical Practice and Self-Determined Learning and Inamadar \& Roldan's [49] capstone business skills into a teaching mentoring practice. The aim was constructed on consilience [52] of these educational concepts (Figure 2) into a cohesive model. The first loop of learning included the worksheets, in class exercises and discussions, the second loop students would undertake assessments to strengthen and reinforce the learnings from the classroom (Figure 2). The daily program was designed to be student centred. This is supported by both Alred and Garvey [53] and Suarez-Barraza and Rofriguez-Gonzael [54] who state that the learner must be at the centre of the process in order for the learning landscape to promote knowledge productivity. The classes were structured so the lecturers could and did inform and mentor the students and thus allow students to plan, apply, do, learn/assess and reflect/improve and create a learning experience and then progress to the next topic. The merged framework formed the daily agenda used to deliver this course which comprised the following phases: Plan phase the lecturers conveyed the applicable subject matter, detailed the subjects purpose, the topics being taught, the exercises and activities that would take place, Apply phase students would undertake in-class group exercises and worksheets, Do phase of the continuous improvement cycle allowed for practical experiences (learning by doing) through individual activities. The third phase Learn/Assess students 
commence assessments centred on subject content and apply knowledge, skills and reflect on insights gained from the application. During this phase students got to know the evaluation process. The lecturers specified and created the detailed marking standard. Students would receive comprehensive feedback from the lecturers (and their peers for some assessments and activities) and were encouraged to make a time to discuss their results. Reflect/Improve final phase: was an opportunity for self-improvement and discovery. Students reflected on their learning to reinforce the subject materials, provided feedback about the course and develop their skills as reflective practitioners seeking continuous improvement. It also presented an opportunity to gain feedback/insights on the subject topics, exercises, activities and assessments and amend programs for the following year. The subject would then move to the next topic area. Lessons were designed to be linked to student assessments as well as their overall MBA. TBS900 was a course in which our students were mentored and supported in their personal knowledge development and reflection. This reflection enabled students to discover their own growth journey from where they began to where they finished. It was a journey controlled by them and their stage of autonomy and empowerment with the learning method [55]. To evolve into heutagogical learners students needed to embrace this style of learning and feel comforted and empowered through their personal motivation and desire to learn and reflect. Only then were students truly able to facilitate their own learnings and advance their capability to apply them during their careers.

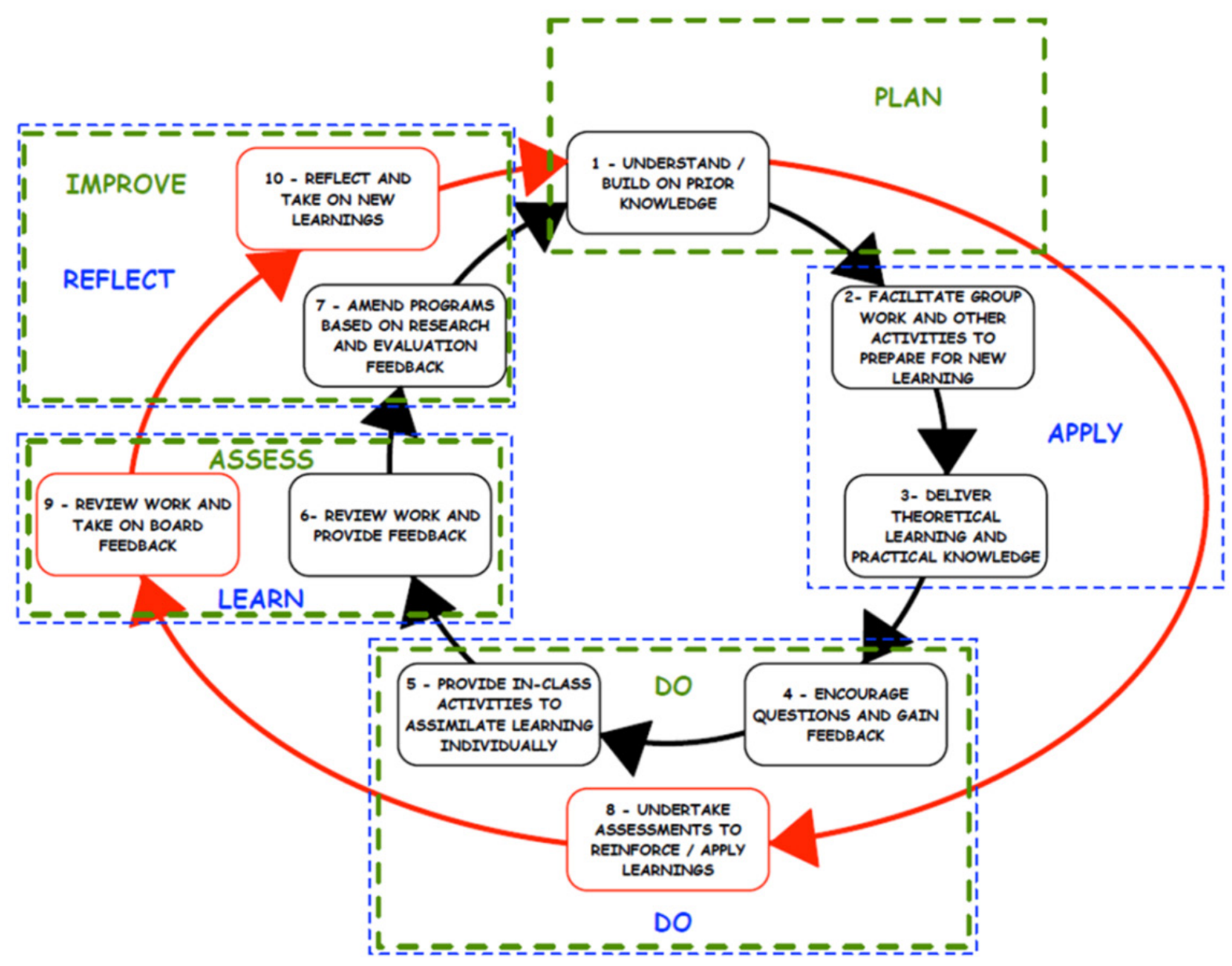

Figure 2. Devised new Heutagogical Learning Cycle Adapted from [21,46-49] 


\section{Outcome}

Discussion of quality in higher education has been limited as Mergen, Grant and Widrick [22] have pointed out and we have contributed to this gap in the literature by applying Aggarwal and Lynn[23] PADI to the development of quality in the higher education context. A key element of the Australian standards is the way that knowledge and skills are applied and brought together to solve multifaceted problems and facilitate lifelong learning. Whitelaw and Wrathall [10] provide a scale of soft and hard skills stating that there is an issue with allocating space to the curriculum for their development. We have developed a model of how to integrate them. The double loop learning cycle supports the findings of Halsall, Powell \& Snowden [29] in that it facilitates the lifelong learning within students. The case supports Inamadar \& Roldan's [49] findings that students are capable of achieving their own success when they have a subject that generates a mentoring environment that provides the tools and strategies needed to facilitate lifelong learning. Success can be reassuringly seen in the overall advancement of student performance from the initial commencement of the subject to latter performance in their final subject. Students became heutagogical learners with the ability to develop an understanding of subject disciplines, applications, address problem and acquire skills that promote continuous learning. A follow up study into students carrying these skills forward into their careers is recommended.

\section{Conclusions}

The purpose of an MBA, by design, is to develop students that have the ability to undertake their careers and be able to be reflective, analytical and critical thinkers, with the ability to address and solve problems, and supported by the drive to be lifelong learners. The PDAI quality management principles provided a framework to apply heutagogical learning to an academic and business skills building subject. There was a need to find a sustainable way to develop student's ability to continuously learn. Aggarwal \& Lynn[23] - a higher education adaptation of the Deming Cycle along with Kolb's[48], Dennick's [50], Blaschke's [51] and Inamadar \& Roldan's [49] models created a double loop quality approach to lifelong learning and offers a way forward to develop student's abilities for independent and continuous fostering of the skills they need to remain competitive in the workforce. This is the first attempt at documenting the process of the developed learning cycle. The purpose of this publication is to describe the development of the process, as well as make available the learning cycle so that this may assist others in the development of courses to meet the higher educational requirements of the organizations they serve.

\section{REFERENCES}

[1] The Commonwealth of Australia. TEQSA Glossary of Terms, Online available from

http://www.teqsa.gov.au/media-publications/glossary, 2012.

[2] Australian Quality Framework Council (AQF), Australian Quality Framework, Online available from http://www.aqf.edu.au/wp-content/uploads/2013/05/AQF2nd-Edition-January-2013.pdf, 2013.

[3] The University of Wollongong (UOW). Sydney Business School Master your career growth: Course Prospectus, Online available from http://sydneybusinessschool.edu.au/content/groups/public/ @web/@bus/documents/doc/uow175926.pdf, 2014.

[4] R. Torraco. Writing Integrative Literature Reviews: Guidelines and Examples, Human Resource Development Review, Vol. 4, No. 3, pp. 356-367. 2005.

[5] R. Whittemore, K. Knafl. The Integrative Review: Updated Methodology, Journal of Advanced Nursing, Vol. 52, No. 5, pp.546-553, 2005.

[6] R. Hall, R. Agarwal, R. Green. The future of management education in Australia: Challenges and innovations, Education and Training, Vol. 55, No. 4, pp. 348-369, 2013.

[7] M. Freeman, P. Hancock. A brave new world: Australian learning outcomes in accounting education, Accounting Education, Vol. 20, No. 3, pp. 265-273, 2011.

[8] G. McCarthy. Sharing the research journey - fostering a love of research in coursework Masters Students, in Mesquita, A. and Ramos, I. (eds.), Proceedings of the 12th European Conference on Research Methodology for Business and Management Studies, Academic Conferences and Publishing International Limited, United Kingdom, pp. 281-288, 2013.

[9] C. Susilawati, C. Eves, L. Bryant, A. Blake. The Australian Qualifications Framework for bachelor degree in property economics, paper presented at the 20th Annual Pacific Rim Real Estate Society Conference, 19-22 January, Lincoln, New Zealand, Online available from http://eprints.qut.edu.au/83855/, 2014.

[10] P. Whitelaw, J. Wrathall. Developing practice oriented undergraduate courses in a quality framework: a case study: bachelor of event management, Quality Assurance in Education, Vol. 23, No. 4, pp. 395-409, 2015.

[11] P. Pryor. Accredited OHS professional education: A step change for OHS capability, Safety Science, Vol. 81, pp. 5-12, 2016.

[12] S. Jackson, R. Mason, M. Toohey. The emergence of the JD in the Australian legal education marketplace and its impact on academic standards, Legal Education Review, Vol. 21, No. 1, pp. 23-48, 2011.

[13] A. Divan, S. Mason. A programme-wide training framework to facilitate scientific communication skills development amongst biological sciences Masters students, 
Journal of Further and Higher Education, Vol. 37, No. 10 pp. 1-25, 2015.

[14] E.E. Leigh. Identifying the Competencies and Capabilities of Simulation Professionals, in: Meijer, S.A. and Smeds, R. (eds.), Frontiers in Gaming Simulation: 44th International Simulation and Gaming Association Conference, ISAGA 2013 and 17th IFIP WG 5.7 Workshop on Experimental Interactive Learning in Industrial Management, Stockholm, Sweden, June 24-28, 2013, Revised Selected Papers, Springer International Publishing, Cham, pp. 253-264, 2014.

[15] R.V. Iyengar. MBA: The soft and hard skills that matter, IUP Journal of Soft Skills, Vol. 9, No. 1, pp. 7-14, 2015.

[16] E. Smith. Voices from a small discipline: How the Australian Vocational Education and Training discipline made sense of journal rankings, International Journal of Training Research, Vol. 12, No. 3, pp. 227-241, 2014.

[17] D.T. Malone, J.L. Short, S. Naidu, P.J. White, C.M. Kirkpatrick. Mapping of the Australian qualifications framework standards onto an undergraduate bachelor of pharmacy course, Pharmacy Education, Vol. 15, No. 1, pp. 261-269, 2015.

[18] M. McAuliffe, D. Hargreaves, A. Winter, and G. Chadwick. Does Pedagogy Still Rule? Australasian Journal of Engineering Education, Vol. 15, No. 1, pp. 13-8, 2009.

[19] J. Cullen, J. Joyce, T. Hassall, and M. Broadbent, Quality in higher education: from monitoring to management, Quality Assurance in Education, Vol. 11, No. 1, pp. 5-14, 2003.

[20] Å. Gornitzka, B. Stensaker. The dynamics of European regulatory regimes in higher education - Challenged prerogatives and evolutionary change, Policy and Society, Vol. 33, No. 3, pp. 177-88, 2014.

[21] J. Newton, Feeding the Beast or Improving Quality?: Academics' perceptions of quality assurance and quality monitoring, Quality in Higher Education, Vol. 6, No. 2, pp. 153-63, 2000.

[22] E. Mergen, D. Grant, and S.M. Widrick. Quality management applied to higher education, Total Quality Management, Vol. 11, No. 3, pp. 345-52. 2000.

[23] A.K. Aggarwal, S.A. Lynn. Using Continuous Improvement to Enhance an Online Course, Decision Sciences Journal of Innovative Education, Vol. 10, No. 1, 25-48. 2012.

[24] S. Hase, C. Kenyon. Heutagogy and developing capable people and capable workplaces: strategies for dealing with complexity, paper presented at the Proceedings of The Changing Face of Work and Learning conference, 25-27 September, University Alberta, Canada. Online available from

http://epubs.scu.edu.au/cgi/viewcontent.cgi?article $=1123 \&$ context=gcm_pubs, 2003.

[25] T.J. van Weert. Education of the twenty-first century: New professionalism in lifelong learning, knowledge development and knowledge sharing, Education and Information Technologies, Vol. 11 No. 3, pp. 217-37, 2006.

[26] S. Hase, C. Kenyon. From andragogy to heutagogy, Ulti-BASE In-Site, December, 2000.
[27] M. Snowden, J. P. Halsall, Self-determined approach to learning: A social science perspective, Cogent Education, Vol. 3, pp. 1-9, 2016.

[28] E.M. Anderson, L.A. Shannon. Towards a conceptualisation of mentoring, in Kelly, T. and Mayes, S. (Ed.), Issues in Mentoring, Routledge, London, pp. 25-34, 1995.

[29] J. P. Halsall, J.L. Powell, M. Snowden. Determined learning approach: Implications of heutagogy society based learning, Cogent Social Sciences, Vol. 2, pp. 1-11, 2016.

[30] J. Kaur, A. Beri, Coping as a life skill for lifelong learning, Man in India, Vol. 96, No. 5, pp. 1365-1376, 2016.

[31] E. van Laar, A.J.A.M. van Deursen, J.A.G.M. van Dijk, J. de Haan. The relation between 21st-century skills and digital skills: A systematic literature review, Computers in Human Behavior, Vol. 72, Supplement C, pp. 577-588, 2017.

[32] J. Visser. Changing learning environments: The real and not so real of reality and virtuality, learning without frontiers, Online available from http://www.unesco.org/education/lwf, 1999.

[33] P.R. Hedberg. Learning through Reflective Classroom Practice: Applications to Educate the Reflective Manager, Journal of Management Education, Vol. 33 No. 1, pp. 10-36, 2009.

[34] J.W. Peltier, A. Hay, W. Drago. Reflecting on Reflection: Scale Extension and a Comparison of Undergraduate Business Students in the United States and the United Kingdom, Journal of Marketing Education, Vol. 28, No. 1, pp. 5-16, 2006.

[35] A. Chandra, J.M. Jr. Sottile. A critical examination of team-teaching of health care administration courses: student, faculty, and administration perspective, Journal of Hospital Marketing \& Public Relations, Vol. 15 No. 2, pp.55-68, 2005.

[36] S.P. Hillege, J. Catterall, B.L. Beale, L. Stewart. Discipline matters: embedding academic literacies into an undergraduate nursing program, Nurse Education in Practice, Vol. 14, No. 6, pp. 686-691, 2014.

[37] N. Murray. Conceptualising the English language needs of first year university students, International Journal of the First Year in Higher Education, Vol. 1, No. 1, pp. 55-64, 2010.

[38] S. Etherington. Academic writing and disciplines, in Friedrich, P. (Ed.), Teaching Academic Writing, Continuum, London, pp. 26-58, 2008.

[39] R. K. Yin. Case study research: design and methods, Sage, Thousand Oaks, Calif, 1994.

[40] M. Hammersley. Case studies in classroom research: a reader / edited by Martyn Hammersley, Open University Press, Milton Keynes, England; Philadelphia, 1986.

[41] R.E. Stake. The art of case study research / Robert E. Stake, Sage Publications, Thousand Oaks, 1995.

[42] A. Bergen, A. While. A case for case studies: exploring the 
use of case study design in community nursing research, Journal of Advanced Nursing, Vol. 31, No. 4, pp. 926-934, 2000 .

[43] B.R. Williams. Disability in the Australian workplace: Corporate governance or CSR issue? Equality, Diversity and Inclusion, Vol. 36, No. 3, pp. 206-221, 2017.

[44] J. Rowley, B. Kupiec-Teahan, E. Leeming. Customer community and co-creation: a case study, Marketing Intelligence \& Planning, Vol. 25, No. 2, pp. 136-146, 2007.

[45] P. Adams. Self-determined learning: heutagogy in action, British Journal of Educational Studies, Vol. 62, No. 4, 476-478, 2014

[46] J. Bauwens, J.J. Hourcade. Making Co-Teaching a Mainstreaming Strategy, Preventing School Failure: Alternative Education for Children and Youth, Vol.35, No. 4, pp. 19-24, 1991.

[47] W.E. Deming. Out of the crisis / W. Edwards Deming, MIT Press, Cambridge, Mass, 2000.

[48] D.A. Kolb. Experiential learning: Experience as the source of learning and development, Prentice-Hall, Englewood Cliffs, N.J, 1984.

[49] S.N. Inamdar, M. Roldan. The MBA Capstone Course: Building Theoretical, Practical, Applied, and Reflective Skills, Journal of Management Education, Vol. 37, No. 6, pp. 747-770, 2013.
[50] R. Dennick. Twelve tips for incorporating educationa theory into teaching practices, Medical Teacher, Vol. 34, No. 8, pp. 618-624, 2012.

[51] L.M. Blaschke. Heutagogy and Lifelong Learning: A Review of Heutagogical Practice and Self-Determined Learning, International Review of Research in Open and Distance Learning, Vol. 13, No. 1, pp. 56-71, 2012.

[52] E.O. Wilson. Consilience: the unity of knowledge, Random House, New York, 1998.

[53] G. Alred, B. Garvey. Learning to Produce Knowledge - the Contribution of Mentoring, Mentoring \& Tutoring: Partnership in Learning, Vol. 8, No. 3, pp. 261-272, 2000.

[54] M.F. Suárez-Barraza, F.G. Rodríguez-González. Bringing Kaizen to the classroom: lessons learned in an Operations Management course, Total Quality Management \& Business Excellence, Vol. 26, No. 9/10, pp. 1002-16, 2015.

[55] N. Canning. Playing with Heutagogy: Exploring Strategies to Empower Mature Learners in Higher Education, Journal of Further and Higher Education, Vol. 34, No. 1, pp. 59-71, 2010.

[56] J. Gerstein, Maker Education: Pedagogy, Andragogy, Heutagogy, Online available from https://usergeneratededucation.wordpress.com/2016/06/14/ maker-education-pedagogy-andragogy-heutagogy/, 2016 